\title{
Influence of storage, temperature, and light on germination of Japanese brome seed
}

\author{
MARSHALL R. HAFERKAMP, MICHAEL G. KARL, AND MICHAEL D. MACNEIL
}

Authors are range scientist, postdoctoral range scientist, and research geneticist USDA-ARS, Fort Keogh Livestock and Range Research Laboratory, Miles City, Mont. 59301.

\begin{abstract}
Japanese brome (Bromus japonicus Thunb.), an alien annual grass, is an important component of some northern mixed-prairie communities. Understanding the relationship between environment and population dynamics for this species is critical for efficient management of infested ranges. Our objective was to determine the germination pattern of seed harvested in the Great Plains with varying collection dates, storage conditions, incubation temperatures, and light regimes. Seeds were collected from inflorescences (nondisseminated seed) during July in Oklahoma and Montana and during November and December in Montana. July collections were stored in paper sacks in laboratory, and November and December collections were divided into thirds and stored in an unheated warehouse, oven-dried at $46^{\circ} \mathrm{C}$, or frozen at $-18^{\circ} \mathrm{C}$. Seeds were germinated in 2 regimes, where temperatures alternated every 12 hours and light was provided during the 12 hours of high temperature. One regime provided 10 days of prechilling $\left(0\right.$ and $\left.10^{\circ} \mathrm{C}\right)$ followed by 18 days of a warm temperature $(8$ and $23^{\circ} \mathrm{C}$ ) (chilling). Another regime consisted of 28 days of the warm temperature (warm). Samples of seeds were also imbibed in the warm regime with 12-hour or intermittent periods of light. July collections germinated rapidly to $>90 \%$ regardless of temperature. November and December collections stored in the warehouse germinated $>70 \%$ in the warm regime, but germination was reduced to $<20 \%$ with chilling, suggesting secondary dormancy was induced by imbibition at $0^{\circ} \mathrm{C}$. Oven drying was the only treatment that consistently reduced maximum germination. Darkness enhanced 7-day germination, but light improved 28-day germination, and more recently collected seeds were more sensitive to light than older ones. These and earlier findings from Kentucky suggest Japanese brome seeds grown in different locations respond similarly to changing environmental conditions.
\end{abstract}

Key Words: Bromus japonicus, dormancy, freezing, Great Plains, harvest date, nondisseminated seed, oven drying

Japanese brome (Bromus japonicus Thunb.), an alien 1 grass, is an important component of certain northern musdprairie communities (Whisenant 1990). Research on this species in the Northern Great Plains focused on seeking methods of control (Currie et al. 1987, Gartner et al. 1978, Whisenant and Uresk 1990) and on modeling dynamics of seedling establishment (Whisenant 1990).

Because it is an annual, perpetuation of the species depends on

\footnotetext{
The authors express appreciation to Dr. Jerry Volesky for seed collection. Drs. Nancy Shaw and Emerenciana Hurd for conducting tetrazolium chloride tests, Bill Creamer, Bryon Bennett, Cheryl Murphy and several summer aids for assistance with seed collection, sample preparation and germination counts, and Mary Ellen French for assistance with graphics.

This paper is a contribution from the USDA-ARS and Montana Agriculatural Experiment Station, Miles City, Mont.

Publication has been approved by the Director of the Montana Agr. Exp. Sta. Journal Ser. J-2843.

Manuscript accepted 31 Jul. 1993.
}

production of seeds that germinate when environmental conditions allow seedling emergence and establishment. Seeds of annual bromes proceed through periods of primary and secondary dormancy (Baskin and Baskin 1981, Hull and Hansen 1974, Young et al. 1969). Dormancy status of seeds declines from early ripening, when seeds are still green, through dissemination which may occur as late as 1 year following production (Evans and Young 1975).

Baskin and Baskin (1981) concluded temperatures in northcentral Kentucky were within the range for germination of Japanese brome seeds from late June until mid December when temperatures approached $0^{\circ} \mathrm{C}$. They reported dispersed seeds could germinate in light or darkness during July through November if soil moisture was available. They also hypothesized that a high percentage of seeds dispersed in winter, when temperatures approached $0^{\circ} \mathrm{C}$, was induced into secondary dormancy and had to undergo a period of afterripening in warm temperatures the following summer before they could germinate the following autumn. Hulbert (1955) reported optimum and maximum temperatures for germination increased with age. Fluorescent light inhibited germination of freshly harvested seed and retarded that of older seed at favorable temperatures. Light stimulated germination of 4-week old seed at 20 to $30^{\circ} \mathrm{C}$, but 1-year old seed germinated optimally in darkness at all temperatures tested.

Previous studies were conducted with seeds produced in the more moderate climates of southeastern and northwestern United States compared to those in eastern Montana. We did not know if Japanese brome seeds produced in the Great Plains will respond similarly. Milby and Johnson (1987) reported dormancy of downy brome (Bromus tectorum L.) seeds, a closely allied species, varies with geographic location. They found downy brome seeds collected in southern Kansas, central Oklahoma, and north Texas required afterripening for at least 3 months to achieve at least $50 \%$ germination. They indicated data from earlier studies suggested similar afterripening requirements were reported for seeds collected in eastern Washington, central Idaho, and central California. In contrast, they reported a high percentage of freshly harvested seed germinated when samples were collected in Montana, northern California, northern and western Nevada, southern Idaho, and northern Utah.

Disseminated Japanese brome seeds are continually exposed to varying conditions of moisture, temperature, and illumination. Developing a better understanding of how varying environments affect seed germination will enhance the ability to predict fluctuations in population dynamics of Japanese brome in the Northern Great Plains. This information is necessary for land managers to efficiently utilize brome infested ranges.

The current study was designed to enhance understanding of the ecology of Japanese brome in the Great Plains. Thus, the germination pattern of nondisseminated Japanese brome seed in the Great Plains was studied with varying collection locations and dates, 
storage conditions, incubation temperatures, and light regimes.

\section{Materials and Methods}

Japanese brome seeds were collected from native range located on the Fort Keogh Livestock and Range Research Laboratory in Miles City, Mont., on 12 July, 21 November, and 30 December 1991 and from El Reno, Okla., on 7 July 1991. Seeds collected in July were stored in paper sacks in the laboratory at about $21^{\circ} \mathrm{C}$ and $50 \%$ relative humidity. Seeds collected during November and December were divided into thirds and stored in an unheated warehouse (maximum and minimum outside temperatures averaged $6.8^{\circ} \mathrm{C}$ and $-7.1^{\circ} \mathrm{C}$, with extremes of 22.2 and $-24.4^{\circ} \mathrm{C}$; relative humidity averaged $60 \%$ with standard deviation of 13.3 ); dried at $46^{\circ} \mathrm{C}$ for 6 to 35 days and stored in a desiccator at room temperature; or stored in a freezer at $-18^{\circ} \mathrm{C}$. Seed viability was determined on each seed lot in 1992 by the tetrazolium chloride test. Viability averaged $98 \%$ for Oklahoma seeds, and 99,96 , and 93\% for Montana seeds collected in July, November, and December, respectively. Weights were determined for each collection after oven drying seeds for at least 24 hours at $105^{\circ} \mathrm{C}$. Weights per 100 seed averaged $239 \mathrm{mg}$ for Oklahoma seeds and 255, 215, and 199 $\mathrm{mg}$ for seeds collected in Montana in July, November, and December respectively.

In 2 studies, 4 replications of duplicate samples of 100 seeds of each collection per storage condition were incubated in $9-\mathrm{cm}$ petri dishes. Each dish contained 2 pieces of a thick medium speed filter paper with high retention supported on a polyurethane foam disc. Distilled water was supplied continuously to the filter-paper-disc apparatus through a cotton wick inserted through a hole in the center of the foam disc. Replications were conducted over time, with a 3-day interval between starting dates.

\section{Study 1}

One study was initiated on 14 January 1992 to investigate the effect of location and date of collection, storage condition, and incubation temperature on seed germination. In this study 1 set of seeds was incubated for 28 days in alternating 12-hour periods of 8 and $23^{\circ} \mathrm{C}$ (warm) with light supplied by cool-white fluorescent bulbs (PAR $=30 \mu$ moles $\mathrm{m}^{-2} \mathrm{sec}^{-1}$ ) during each 12 -hour $23^{\circ} \mathrm{C}$ period. Another set of seeds was incubated initially for 10 days in alternating 12-hour periods of 0 and $10^{\circ} \mathrm{C}$ and then transferred to the 8 and $23^{\circ} \mathrm{C}$ chamber for the remaining 18 days (chilling). Light was supplied with cool-white fluorescent bulbs during the 12 hours at $10^{\circ} \mathrm{C}$.

Controlled rather than field environments were used to subject seeds to prechilling during imbibition. Use of this treatment was based on the assumption that seed disseminated during late fall, winter, or early spring would have to imbibe at temperatures near $0^{\circ} \mathrm{C}$ in the Great Plains as the seasons progressed from winter to spring or during warming periods in winter.

Germinated seeds were counted daily and removed from the dishes when the radical and coleoptile were each at least 5-mm long. Data were reduced by fitting the cumulative response function.

$$
Y=\max \left(1-1 / 1+\left(\text { day } / G_{50}\right)^{S L P}\right),
$$

to the cumulative proportion of seeds germinated each day. The parameters max, $\mathbf{G}_{50}$, and SLP estimate the maximum proportion germinated, the day on which $50 \%$ of max have germinated, and the rapidity of germination, respectively. Effects of varying the parameters individually on patterns of germination are shown in Figure 1. The estimated parameters, defining temporal germination response to experimentally imposed conditions, were subsequently analyzed with 2 analyses of variance. One compared Oklahoma and Montana seeds stored in the laboratory or warehouse
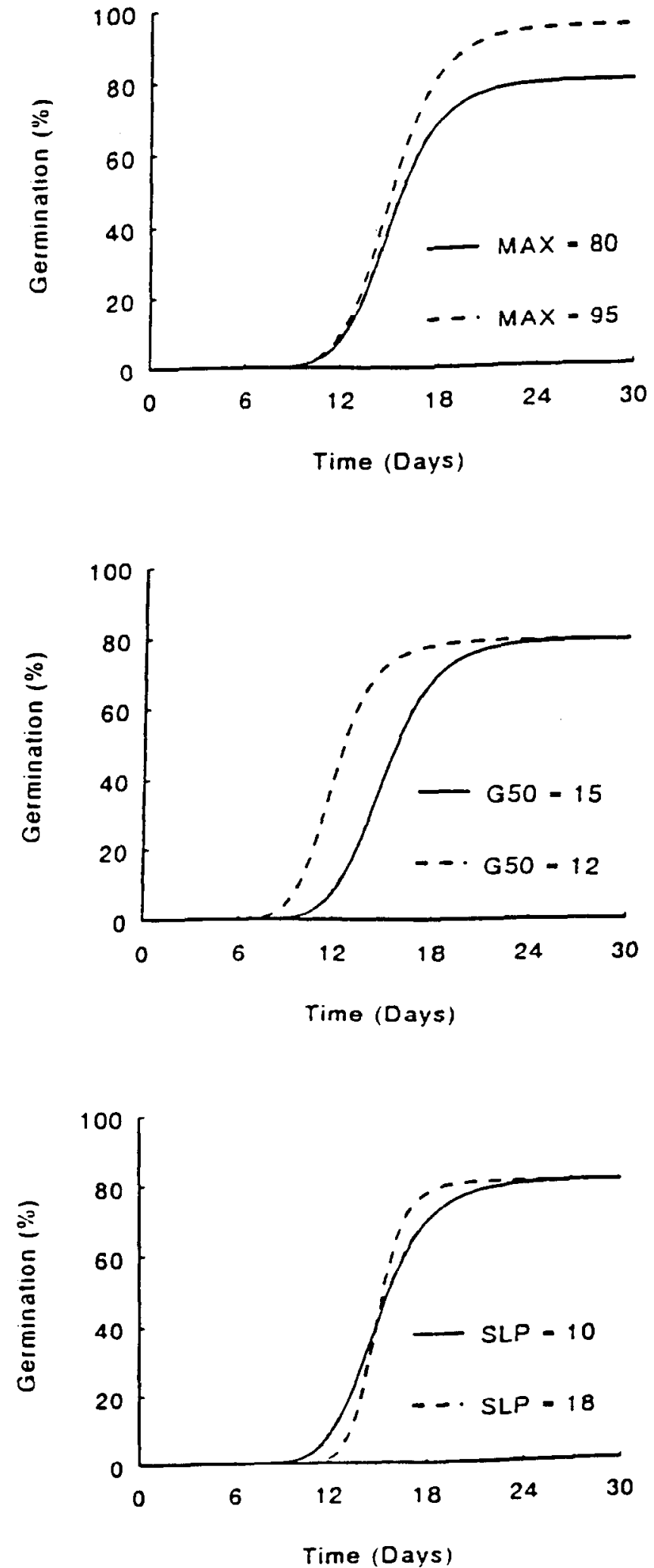

Fig. 1. Effects of individually varying the parameters maximum germination (max), day to $50 \%$ maximum germination $\left(G_{50}\right)$ and rapidity of germination (SLP) on the shape of the germination response function.

and analyzed the effects of seed source, collection date (July, November, and December), and incubation temperature (warm and chilling), A second analysis with only Montana seeds collected in November and December, compared effects of storage conditions (ware- 
house, oven-dried, and frozen) and incubation temperatures (warm and chilling) on patterns of germination. Means were separated by Fischer's Least Significant Difference at $p \leq 0.05$.

\section{Study 2}

In this study initiated on 21 February 1992, we compared the effect of location and date of collection, storage conditions, and light on Japanese brome seed germination when light was applied in daily 12-hour exposures or intermittently (about 5 min. duration) during weekly germination counts. Seeds were incubated for 28 days in the 8 and $23^{\circ} \mathrm{C}$ regime, with light supplied for 12 hours during the $23^{\circ} \mathrm{C}$ by cool-white fluorescent bulbs (PAR $=30 \mu$ moles $\mathrm{m}^{-2} \mathrm{sec}^{-1}$ ). One set of dishes was wrapped in aluminum foil to exclude light, except when seeds were counted. Nonwrapped dishes were placed in an unsealed plastic bag. This procedure was used to reduce and equalize evaporation rates between the 2 sets of dishes.

Germinated seeds were counted and removed every 7 days using the criteria of Study 1. The less frequent counting of germinating seeds led to a data structure that was insufficient for fitting the cumulative response function used in Study 1. Therefore, a repeated measures analysis of variance was used to determine the effects of seed source, storage conditions, and light on log transformed proportion of germinated seeds. Tests of significance for treatment effects (averaged over time) used variation among dishes treated alike as error, and hypotheses concerning the time course of events used the residual mean square as error. Means of the transposed data were separated using Fischer's Least Significant Difference $(p \leq 0.05)$. Figures were plotted from the estimated means after back-transformation and multiplication by 100 to derive percent germination.

\section{Results}

\section{Study 1}

\section{Laboratory and Warehouse Storage-All Seed Lots}

The temperature-by-source interaction was significant for maximum germination, days to $50 \%$ germination, and rapidity of germination when seeds were stored in the laboratory or unheated warchouse (Table 1). Maximum germination of Oklahoma and Montana seeds collected in July and stored in the laboratory averaged $>90 \%$, whether seeds were incubated in the chilling or warm regimes. Germination of Montana seeds collected in July was $8 \%$ greater in the warm compared to the chilling regime, whereas seeds collected in November and December germinated 5 to 14 fold more in the warm compared to the chilling regime. A smaller proportion of seeds collected in November and December germinated than seeds collected in July in Montana. Further, a smaller proportion of seeds collected in December germinated compared with seeds collected in November.

Judging from the days required to reach $50 \%$ maximum germination $\left(G_{50}\right)$, seeds collected from both locations on all dates required a longer period of time to germinate in the chilling compared to the warm regime (Table 1). Germination of all seed was
Table 1. Maximum germination (\%), rate of germination (days to 50\%), and rapidity of germination (slope) in 2 temperature regimes for Japanese brome seed collected in Oklahoma and Montana in July 1991 and in Montana in November and December 1991. Summer collections were stored in a laboratory and fall and winter collections were stored in an unheated warehouse.

\begin{tabular}{|c|c|c|c|c|}
\hline \multirow[b]{2}{*}{ Temperature } & \multirow{2}{*}{$\frac{\text { Oklahoma }}{7 \mathrm{Jul} .}$} & \multicolumn{3}{|c|}{ Montana } \\
\hline & & 12 July. & 21 Nov. & $30 \mathrm{Dec}$. \\
\hline $\begin{array}{l}0 \text { and } 10^{\circ} \mathrm{C}+8 \text { and } 23^{\circ} \mathrm{C} \\
8 \text { and } 23^{\circ} \mathrm{C}\end{array}$ & $\begin{array}{c}99 \\
100\end{array}$ & $\begin{array}{c}92 \\
92 \\
100 \\
\text { LSD }\end{array}$ & $\begin{array}{r}18 \\
88 \\
.05=4\end{array}$ & $\begin{array}{r}5 \\
71\end{array}$ \\
\hline $\begin{array}{l}0 \text { and } 10^{\circ} \mathrm{C}+8 \text { and } 23^{\circ} \mathrm{C} \\
8 \text { and } 23^{\circ} \mathrm{C}\end{array}$ & 14 & $\begin{array}{c}\text { (days to } \\
15 \\
8 \\
\text { LSD }\end{array}$ & $\begin{array}{r}0 \%) \\
16 \\
10 \\
.05=2\end{array}$ & $\begin{array}{l}18 \\
12\end{array}$ \\
\hline $\begin{array}{l}0 \text { and } 10^{\circ} \mathrm{C}+8 \text { and } 23^{\circ} \mathrm{C} \\
8 \text { and } 23^{\circ} \mathrm{C}\end{array}$ & $\begin{array}{l}---- \\
38 \\
5\end{array}$ & $\begin{array}{c}\text { - (slope } \\
16 \\
10 \\
\text { LSD }\end{array}$ & $\begin{array}{r}17 \\
6 \\
0=5\end{array}$ & $\begin{array}{r}14 \\
5\end{array}$ \\
\hline
\end{tabular}

delayed during the 10 -day period at 0 and $10^{\circ} \mathrm{C}$. In the chilling regime, seeds collected in December required more time to reach $50 \%$ maximum germination than other collections, while in the warm regime December collections required more time than other Montana seeds, but requirements were similar to those of Oklahoma seeds.

Rate of germination was consistently slowest over the 28-day period in the chilling regime (Table 1). Seeds germinated rapidly at 8 and $23^{\circ} \mathrm{C}$ following 10 days of chilling at 0 and $10^{\circ} \mathrm{C}$, during which no seeds germinated. Germination advanced some during the chilling period if only from water imbibition as evidenced by the magnitude of increase in rapidity of germination ranging from 1.6 fold for Montana seeds collected in July to 7.6 fold for Oklahoma seeds as the seeds were transferred from the 0 and $10^{\circ} \mathrm{C}$ to 8 and $23^{\circ} \mathrm{C}$ temperatures. The rate of germination for all seed sources was similar in the warm regime.

Storage Conditions-November and December Collections

Storage conditions differentially affected germination of seeds collected in November and December as reflected by the significant source-by-temperature-by-storage interaction (Table 2). However, temperature effects alone accounted for 10 -fold more variation than any other effect examined. Germination was consistently greater in the warm $(65 \pm 1 \%)$ (mean \pm standard error) than in the chilling ( $11 \pm 1 \%)$ regime, and germination was similar in the chilling regime regardless of storage condition. Highest germination was attained by November collections when stored in the warehouse or freezer and incubated in the warm regime. Highest germination of December seeds occurred when stored in the warehouse, lowest when oven-dried, and intermediate when frozen.

The time required to reach $50 \%$ of maximum germination was similar for November and December collections stored in the 3

Table 2. Maximum germination (\%) in 2 temperature regimes for Japanese brome seed collected in November and December 1991 in Montana. Storage was in an unheated warehouse, oven-dried, or frozen.

\begin{tabular}{|c|c|c|c|c|c|c|}
\hline \multirow[b]{2}{*}{ Temperature } & \multicolumn{3}{|c|}{ November } & \multicolumn{3}{|c|}{ December } \\
\hline & Warehouse & Oven-dry & Frozen & Warehouse & Oven-dry & Frozen \\
\hline $\begin{array}{l}0 \text { and } 10^{\circ} \mathrm{C}+8 \text { and } 23^{\circ} \mathrm{C} \\
8 \text { and } 23^{\circ} \mathrm{C}\end{array}$ & $\begin{array}{l}18 \\
88\end{array}$ & $\begin{array}{l}17 \\
63\end{array}$ & $\begin{array}{l}20 \\
90\end{array}$ & $\begin{array}{r}5 \\
71\end{array}$ & $\begin{array}{r}1 \\
23\end{array}$ & $\begin{array}{r}2 \\
53\end{array}$ \\
\hline
\end{tabular}


regimes, ranging from 14 to 17 days. The temperature-by-source interaction was significant, reflecting the significant divergence between time required for the November (12 days) and December (15 days) collections to reach $50 \%$ maximum germination in the warm regime, while no difference ( 17 and 18 days) was observed in the chilling regime. A significant storage-by-temperature interaction occurred when warehouse and frozen seeds required fewer days to germinate than oven-dried seeds in the warm but not the chilling regime (Table 3 ).

Table 3. Days to $50 \%$ germination $\left(G_{50}\right)$ in 2 temperature regimes for Japanese brome seed collected in Montana in November and December 1991. Seeds were stored in an unheated warehouse, oven-dried, or frozen.

\begin{tabular}{|c|c|c|c|}
\hline Temperature & Warehouse & Oven-dry & Frozen \\
\hline $\begin{array}{l}0 \text { and } 10^{\circ} \mathrm{C}+8 \text { and } 23^{\circ} \mathrm{C} \\
8 \text { and } 23^{\circ} \mathrm{C}\end{array}$ & $\begin{array}{c}17 \\
11\end{array}$ & $\begin{array}{l}\text { ays to } 50 \% \\
17 \\
16 \\
\text { LSD }_{0.0}\end{array}$ & $\begin{array}{l}17 \\
12\end{array}$ \\
\hline
\end{tabular}

Germination rate was only affected by temperature. The rapidity of germination (SLP) was nearly 3 fold greater in the chilling regime than in the warm regime.

\section{Study 2}

When Japanese brome seeds were incubated in intermittent compared to alternating 12-hour periods of darkness and light in 8 and $23^{\circ} \mathrm{C}$, a significant source-by-storage-by-light interaction occurred for total germination. July collections from Oklahoma and Montana stored in the laboratory germinated $>95 \%$ by day 7 . Germination increased to $98 \%$ on later dates and was similar between the 2 collections and light treatments regardless of counting date.

Germination of seeds collected in November was consistently greater with storing in the warehouse or freezer compared to oven drying except on day 28 (Fig. 2). Regardless of storage conditions,

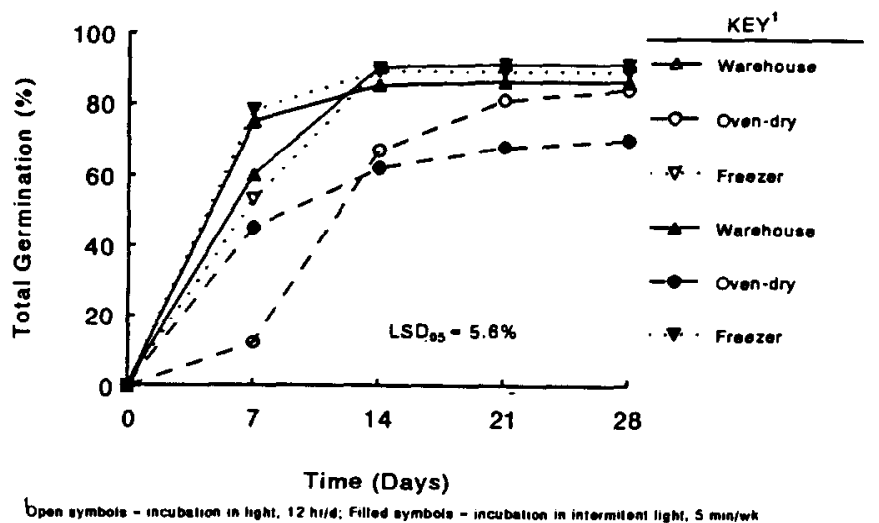

Fig. 2. Germination of Japanese brome seed collected in November, stored in an unheated warehouse, oven-dried, or frozen and imbibed for 28 days in an 8 and $23^{\circ} \mathrm{C}$ temperature regime in intermittent light or with alternating light for 12 hours at the high temperature.

seed germination in intermittent light exceeded that in 12 hours of light on day 7. Seeds stored in the warehouse or freezer germinated similarly in intermittent or 12-hour periods of light on days 14,21, and 28 , while germination of oven-dried seeds imbibed in 12 hours of light exceeded germination in intermittent light on days 21 and 28.

Germination profiles of seeds collected during December were more sensitive to storage conditions and light regimes than seeds from November collections. Within light regimes, germination of seeds collected during December and stored in a warehouse consistently exceeded germination of seeds stored in a freezer, and germination of frozen seeds exceeded germination of oven-dried seeds (Fig. 3). Germination of seeds collected during December was higher in intermittent than 12 hours of light for the first 7 days.

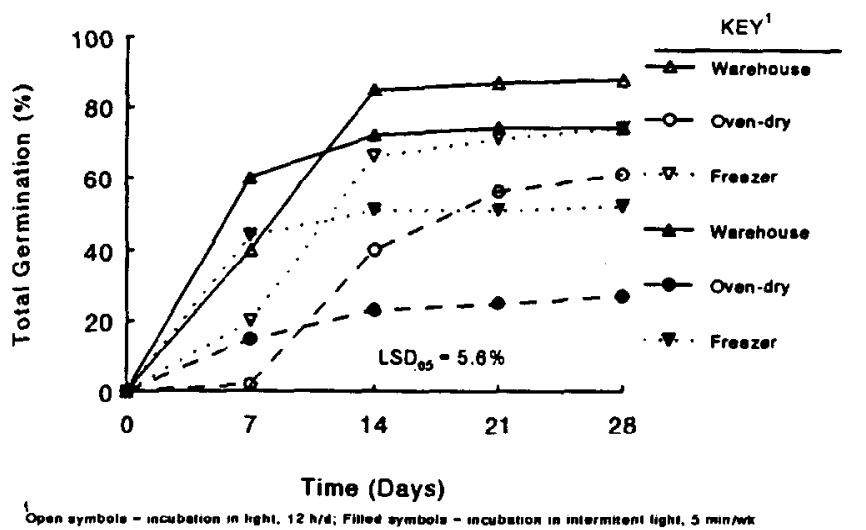

Fig. 3. Germination of Japanese brome seed collected in December, stored in an unheated warehouse, oven-dried, or frozen and imbibed for 28 days in an 8 and $23^{\circ} \mathrm{C}$ temperature regime in intermittent or with alternating light for 12 hours at the high temperature.

However, between days 7 and 14 a consistent reversal occurred and thereafter germination in 12 hours of light exceeded that in intermittent light for all storage conditions.

\section{Discussion}

Results clearly show that germination of Japanese brome seeds can occur over a wide range of environmental conditions. More than $70 \%$ of seeds collected from inflorescences during November and December germinated, and nearly $100 \%$ of seeds from July collections germinated rapidly (Table 1). Seeds, however, harvested during November and December entered secondary dormancy when they imbibed water and temperatures approached $0^{\circ}$ C. These findings agree with Baskin and Baskin (1981) for Japanese brome in northcentral Kentucky and with Hull and Hansen (1974) for downy brome in Utah and Idaho.

It is understandable how seedlings may become established each fall when rains begin to moisten the soil surface. Fifty percent of the seeds stored in a laboratory or warehouse germinated in 8 to 12 days at 8 and $23^{\circ} \mathrm{C}$ with a constant water source (Table 1). We suspect surface soils in many instances will remain moist for at least a week with the onset of fall rains in the Northern Great Plains, and the length of the moist period will be increased with the presence of a mulch layer that reduces moisture loss through evaporation.

Imbibition in the chilling regime reduced maximum germination of seeds collected in November and December by 80 and $93 \%$ compared to seed imbibed in the warm regime (Table 1). Thus, only 7 to $20 \%$ of the seeds in our study appear to have the potential to germinate in spring if dormant seeds from Montana respond similarly to those from Kentucky and do not germinate until the following fall. We can only speculate on the future of the dormant seed population, since this aspect was not investigated in the current study. There is, however, evidence that germination patterns of seeds of annual grasses vary with geographic location (Milby and Johnson 1987).

Imbibition of July collections in the chilling regime (Table 1) reduced rate of seed germination slightly for 3 and 7 days for the Oklahoma and Montana collections, respectively, when compared to the warm regime, but total germination was not affected. Thus, the germination process advanced in these seeds during chilling 
even if at a slower rate. Imbibition of water and physiological development was reported for crested wheatgrass [Agropyron desertorum (Fisch. ex Link) Schult.] seeds incubated at low temperatures (Wilson 1973).

Of the 3 storage regimes tested, oven-drying and storing over desiccant was the most detrimental to germination (Table 2) with greatest reductions occurring in the 8 and $23^{\circ} \mathrm{C}$ regime for seeds collected in December. Probert (1992) also reported that even partial desiccation of freshly harvested seeds can increase sensitivity to dormancy regulating factors. This environment might exist for summer dispersed seed, but it is not a treatment that would occur naturally to seeds dispersed during fall or winter. Its importance is related to subsequent seed research, as seeds are often collected and dried before storage for use in future research. Freezing only reduced germination of December collections. Storage in freezing temperatures may have simply reduced the rate of afterripening.

Rarely has the response of Japanese brome seeds to light been reported. Hulbert (1955) reported fluorescent light was inhibitory for new and retarding for older seed at favorable temperatures. This work, however, appears to have been conducted in continuous light or darkness with constant temperatures. Baskin and Baskin (1981) germinated seed in alternating periods of light and darkness, or seeds were imbibed in field conditions and germination was counted only after 30-day imbibition. In our study, light generated by cool-white fluorescent bulbs reduced germination during the first 7 days of imbibition, but generally enhanced germination over the 28-day period (Figs. 2 and 3 ). Response to light also appeared related to seed age. Light did not affect germination of July collections, had a minimal effect on total germination of all except oven-dried November collections, but had a large effect on maximum germination of December collections at 7 and 28 days.

Germination was quite high with only intermittent light during weekly germination counts. If we exclude the oven-drying treatment, over $40 \%$ of the seeds collected in November and December and $95 \%$ of the seeds collected in July germinated in intermittent light. It is thus apparent how seeds may germinate readily under a litter cover that restricts light and reduces moisture evaporation. Care must be taken, however, when forming hypotheses relative to field germination and emergence since the spectral composition of radiation incident on the seed can be affected by many factors, e.g., time of day, seasonal meteorological conditions, snow cover, shallow burial in soil, and transmission characteristics of the overstory vegetation (McDonough 1977).

In our study, 12-hour photoperiods were used. Simpson (1990) interpreted Baskin and Baskin (1981) data to suggest that a combination of low temperatures and short days at the soil surface induced secondary dormancy during the winter. Our results with 12-hour photoperiods concur that cool temperatures may be a factor in this phenomena. We do not have any direct evidence concerning day length, but day length may not be as important.

\section{Management Implications}

These and earlier findings clearly indicate Japanese brome seeds from Oklahoma, Montana, and Kentucky respond similarly to changing environmental conditions. The results of this series of studies are important because they describe characteristics of Japanese brome that indicates it may be a component of Northern Great Plains rangelands for years to come. Other germination studies (Haferkamp, unpublished data) showed temperature is likely not a limiting factor for fall germination of Japanese brome seed that is disseminated in summer or fall. If soil moisture is adequate, high levels of germination will often occur during the initial fall period. This results in a large population of Japanese brome seedlings that can overwinter and renew growth early the following spring.

As with downy brome, complete germination of all seeds in 1 season is rare (Hull and Hansen 1974). Seeds which are not disseminated or do not germinate in the fall overwinter as seeds and potentially enter a state of secondary dormancy. Only a small proportion may germinate before the next fall.

The germination process appears to shift in response to moisture and temperature from one in which most seeds germinate at once to one in which seed germination is delayed with only a few seeds germinating at any one time. These processes result in a carryover of a large number of viable seeds from year to year, complicating control of Japanese brome through conventional means. Japanese brome seed germination characteristics also aid its future invasion and perpetuation on rangelands in the Northern Great Plains.

\section{Literature Cited}

Baskin, J.M., and C.C. Baskin. 1981. Ecology of germination and flowering in the weedy winter annual grass Bromus japonicus. J. Range Manage. 34:369-372.

Currie, P.O., J.D. Volesky, T.O. Hilken, and R.S. White. 1987. Selective control of annual bromes in perennial grass stands. J. Range Manage. 40:547-550.

Evans, R.A., and J.A. Young. 1975. Enhancing germination of dormant seeds of downy brome. Weed Sci. 23:354-357.

Gartner, F.R., R.I. Butterfeld, W.W. Thompson, and L.R. Roath. 1978. Prescribed burning of range ecosystems in South Dakota, p. 687-690. In: D.N. Hyder (ed.). Proc. 1st Int. Rangeland Congr. Soc. Range Manage., Denver, Colo.

Hulbert, L.C. 1955. Ecological studies of Bromus tectorum and other annual bromegrasses. Ecol. Monogr. 25:181-213.

Hull, A.C. Jr., and W.T. Hansen, Jr. 1974. Delayed germination of cheatgrass seed. J. Range Manage. 27:366-368.

McDonough, W.T. 1977. Seed physiology, p. 155-184. In: R.E. Sosebee (ed.), Rangeland plant physiology. Range Sci. Ser. No. 4. Soc. Range Manage., Denver, Colo.

Milby, T.H., and F.L. Johnson. 1987. Germination of downy brome from southern Kansas, central Oklahoma, and north Texas. J. Range Manage. 40:534-536.

Probert, R.J. 1992. The role of temperature in germination ecophysiology, p. 285-325. In: M. Fenner (ed.), Seeds. The ecology of regeneration in plant communities. CAB Int.

Simpson, G.M. 1990. Seed dormancy in grasses. Cambridge Univ. Press. Cambridge.

Whisenant, S.G. 1990. Postfire population dynamics of Bromus japonicus. Amer. Midl. Natur. 123:301-308.

Whisenant, S.G., and D.W. Uresk. 1990. Spring burning Japanese brome in a western wheatgrass community. J. Range Manage. 43:205-208.

Wilson, A.M. 1973. Responses of crested wheatgrass seeds to environment. J. Range Manage. 26:43-46.

Young, J.A., R.A. Evans, and R.E. Eckert, Jr. 1969. Population dynamics of downy brome. Weed Sci. 17:20-26. 